\title{
Emerging Technologies, Corporate Social Responsibility and Sustainability: The Perception of Business Students in Ghana
}

\author{
King Carl Tornam, Duho \\ Department of Accounting \\ University of Ghana Business School \\ Accra, Ghana \\ https://orcid.org/0000-0002-8736-3220 \\ Samuel Nana Yaw, Simpson \\ Department of Accounting \\ University of Ghana Business School \\ Accra, Ghana \\ snysimpson@ug.edu.gh
}

\author{
Joseph Mensah, Onumah \\ Department of Accounting \\ University of Ghana Business School \\ Accra, Ghana \\ jmonumah@ug.edu.gh \\ Regina Mensah, Onumah \\ Department of Accounting \\ GIMPA \\ Accra, Ghana \\ rmonumah@gimpa.edu.gh
}

\begin{abstract}
The present fourth industrial revolution is characterized by concerns for technological advancement. Studies in literature have examined the factors that affect the perception of business students towards either corporate social responsibility or sustainability or both. Yet, there has not been any study that examines how students' embracing, knowledge and ability to make business cases out of these emerging technologies affect either corporate social responsibility or sustainability. The current study filled this gap by using a survey dataset of 150 business students of the University of Ghana Business School. The study employed the partial least squares structural equation modelling to examine the relationships. Generally, the students have a relatively higher concern for corporate social responsibility and sustainability. As regards the knowledge of emerging technologies, responses are just a little above average. The top four technologies with high student knowledge are the internet of things, mobility technology, digital service delivery and cybersecurity while the bottom four are blockchain, quantum computing, big data analytics, and robotics. The study found that students that embrace emerging technologies eventually take steps to increase their knowledge in these technologies but the knowledge may not necessarily enhance the concern for corporate social responsibility and sustainability. It is when students embrace the new technologies and eventually make business cases and envisage implications from them that they get concerned about issues of corporate social responsibility and sustainability. We propose for more case study based teaching about issues in emerging technologies tied to corporate ethics - corporate social responsibility and sustainability. The study offered relevant insights for policy, practice and academia.
\end{abstract}

Keywords - emerging technologies, corporate social responsibility, sustainability, business students, partial least square, structural equation modelling, Ghana

This paper can be cited as: Duho, K.C.T., Onumah, J.M., Simpson, S.N.Y. and Onumah, R. M. (2019) Emerging Technologies, Corporate Social Responsibility and Sustainability: Perception of Business Students in Ghana. Academy of International Business (AIB) Africa Conference 4-7 August 2019, Accra, Ghana.

\section{INTRODUCTION}

One of the key characteristics of the fourth industrial revolution is a high extent of technological change - a time of cyber-physical systems [1, 2]. Emerging technologies continue to flood the world with high disruptive power for various industries. Ethical issues are key in considering these technologies and for their use in the business world [3, 4]. Ethical concerns in the corporate world are tied to corporate social responsibility (CSR) and sustainability. In spite of the relevance of the need to understand how students perceive these technologies and the implications for CSR and sustainability, there is a paucity of literature in this area. Studies have examined the factors that determine student's perception of either CSR or sustainability or both but without exploring how emerging technologies come to play in affecting this perception [5-8]. CSR encompasses the responsibility of a business to its society economically, ethically, legally and morally $[9,10]$. This study views sustainability to be more forward-looking. Sustainability, in this case, suggests the ability to meet present needs without undermining the needs of posterity [9, 11]. Emerging technologies are operationalized in this study to represent those technologies that have not been fully developed or gained major application but are in the initial stages of development and/or usage.

There is a belief that emerging technologies are altogether unethical [12]. The concern of the ethical stance of these technologies is basically based on the various safety and risk issues that are associated with the technologies [12, 13]. To what extent do students get concern for CSR and sustainability or otherwise as they embrace these technologies, gain knowledge about them or eventually envisage the business relevance of the technologies? This study addressed this question by employing the partial least squares structural equation modelling to examine how embracing, knowledge and the ability of students to make business cases from emerging technologies affect CSR and sustainability using a dataset of 150 graduate and undergraduate students of University of Ghana Business School. To be specific the study addressed how the insurgence of emerging technologies influence students' perception of CSR and sustainability. 
The rest of the paper is organized in the following manner. The next section provides a brief literature review followed by the research methodology. Section 4 presents the results of the study while section 5 provides the conclusion and summary of results with implications of the same.

\section{LITERATURE REVIEW}

\section{A. CSR, Sustainability and Emerging Technologies Nexus}

In the extant literature, there are a number of perception based studies which examined the perception of business students on CSR and sustainability themes [5, 8, 14]. These studies provide a measure of the perception of students and examine what factors contribute to high levels among students. There are two main strands of studies available in the CSR and sustainability literature in the area of finding the perception of students. One strand focus on ethics and CSR and how students perceive them, as well as, what factors motivate the choice of students $[6-8,14]$. The other strand focus on the perception of students towards sustainability themes [15-17]. The first disparity is that the ethics and CSR studies mostly examined the perception of business students while sustainability studies examine the whole population of university students. Secondly, the first strand made use of the implications of shareholder and stakeholder theory while the second strand makes use of the triple bottom line. Thirdly, studies in the first strand mostly examine the impact of some variables in explaining the disparity in perception while most studies in the second strand employ descriptive analysis without any statistical test and inference. Technology has the potential to either lead to sustainability or unsustainability depending on how it has been used [18]. Johnson and Brennan [19] found that technology plays a critical role in enhancing corporate social practices. While concerns for emerging technologies is growing in the literature, there is little on the embracing, knowledge and ability of students to make business cases out of emerging technologies. Parasuraman [20] developed a technology readiness index which aimed at measuring the readiness of customers in adopting technologies. This constructs in spite of their relevance in the case of customers do not apply to students. There are myriads of emerging technologies that are of use for students in the business school. There is a paucity of literature on this especially in the context of an emerging economy like Ghana.

\section{METHODOLOGY}

\section{A. Design, Research Instrument and Data Collection}

The survey method was used to collect data from the respondents and the quantitative method of analysis employed. The questionnaire covered the demographics of the respondents, their perception of CSR and sustainability. In addition, the knowledge of students on emerging technologies, how they embrace these technologies and the business cases they make of these technologies in impacting business has been explored. The study employed an adapted version of the questionnaire used in Larrán, et al. [5], AlonsoAlmeida, et al. [6], and Lämsä, et al. [14] to measure CSR and sustainability. A 10-Likert scale has been employed for the study to inculcate more variability. The data was collected in class during the second semester of the 2018/2019 academic year. The respondents are from both the undergraduate and graduate level covering all the seven specialization areas available at the University of Ghana Business School. In total, a sample size of 200 questionnaires was administered to the students with a return rate of $77 \%$. This sample size is valid considering the 10 times rule of Barclay, et al. [21] which propose that the sample size should be at least 10-times the highest number of indicators of the constructs under considering which in this case will have resulted in a minimum sample size of 120 .

\section{B. Data Management and Analysis}

The structural equation modelling is used for this study [22]. This technique is robust to sample size issues, it accounts for measurement errors in observed variables, it is preferable for exploratory analysis, it works with non-parametric data and it provides a path model to pictorially depict the relationship explored [23-25]. First, the demographic data is analyzed using SPSS [26]. Various tests such as reliability and validity tests, blindfolding test among others are then conducted to ensure that all their scores are at the acceptable levels. The study then proceeded to employ the bootstrap method using 5,000 re-sampling sizes to estimate the regression model and its p-values. The importance of bootstrapping is that it gives the researcher the ability to provide a generalization to the result obtained.

\section{RESULTS}

\section{A. Demographics}

In total, 152 students filled the questionnaire out of which 34 $(22.4 \%)$ are postgraduate students and $118(77.6 \%)$ undergraduate students. Also, 62 (40.8\%) were male while 90 $(59.2 \%)$ were female students. As regards the age groups, 45 $(29.6 \%)$ fall below age $20,95(62.5 \%)$ are from age 20 to 25 , $1(0.7 \%)$ aged from 31 to 40 while $3(2 \%)$ are aged above 40 years. Again, $82(53.9 \%)$ indicated that they had some level of working experience while $70(46.1 \%)$ do not have any working experience.

\section{B. Descriptive Statistics}

In Table I, the results of the descriptive statistics on CSR provides a grand mean of $8.71(\min =8.22, \max =9.07)$ which is bigger the grand mean of 8.37 ( $\min =7.26$, $\max =8.89$ ) reported in Larrán, et al. [5] which was conducted in the Spanish context. This high figure suggests that Ghanaian business students are more concerned with CSR than the Spanish students examined. In like manner, sustainability is perceived in the Ghanaian context with a grand mean of 8.79 $(\min =8.31, \max =9.07)$ as compared to that recorded in Larrán, et al. [5] with a grand mean of 7.78 ( $\min =6.90$, $\max =8.58$ ). 
TABLE I

DESCRIPTIVE

\begin{tabular}{cllc} 
SUSTAINABILITY & Mean & SD \\
\hline Notations & Items & 8.7064 & \\
& Corporate Social Responsibility & 8.9070 & 2.2490 \\
RES9 & Satisfy customer needs & 8.9200 & 1.9980 \\
RES10 & Comply with all laws and regulations & 8.2200 & 2.4130 \\
RES11 & Offer equal-opportunity employment & 8.5330 & 2.1990 \\
RES12 & Ensure confidentiality and control the use or transfer of & & \\
& information & 8.6070 & 2.0680 \\
RES13 & Enhance environmental conditions & 8.6380 & 1.9870 \\
RES14 & Create value for the local community in which it operates & 8.6330 & 2.1830 \\
RES15 & Invest in the growth and well-being of Employees & 9.0730 & 1.8620 \\
RES16 & Produce useful and high-quality goods/services & 8.8270 & 2.0160 \\
RES17 & Maximize value for shareholders & 8.7855 & \\
& Sustainability & 8.8530 & 2.1150 \\
SUS18 & Creates products or services that benefit society & 8.7400 & 2.0990 \\
SUS19 & Operates according to its values and a strong code of ethics & 8.8470 & 1.8820 \\
SUS20 & Adheres to progressive environmental policies & 8.3130 & 2.1170 \\
SUS21 & Is a stable employer & 8.8000 & 1.8940 \\
SUS22 & Invests in employee training and development & 8.8000 & 2.1040 \\
SUS23 & Adheres to a strong mission & 9.0670 & 1.9620 \\
SUS24 & Provides excellent customer service & 8.4930 & 2.0780 \\
SUS25 & Offers high financial return to shareholders & 8.8130 & 1.8630 \\
SUS26 & Has efficient and flexible operations & 9.0400 & 1.8580 \\
SUS27 & Produces high-quality products and services & 8.8470 & 1.8750 \\
SUS28 & Attracts and retains exceptional people & 8.8130 & 1.8310 \\
SUS29 & Provides competitive compensation & &
\end{tabular}

The descriptive statistics pertaining to emerging technologies are also reported in Table II and III. The results indicated a grand mean of $8.64(\min =8.31$, $\max =8.88)$ suggesting that business students in Ghana are able to make business cases out of emerging technologies. Also, embracing emerging technologies recorded a grand mean of 7.29 ( $\mathrm{min}=4.42$, $\max =8.34$ ). This depicts the extent to which some facets are embraced while others are not. For instance, while the majority of students believe emerging technologies will have a positive impact on their profession, most have not had any programming experience or have not taken the pain to learn about it.

The descriptive statistics pertaining to emerging technologies are also reported in Table II and III. The results indicated a grand mean of $8.64(\min =8.31$, $\max =8.88)$ suggesting that business students in Ghana are able to make business cases out of emerging technologies. Also, embracing emerging technologies recorded a grand mean of 7.29 ( $\mathrm{min}=4.42$, $\max =8.34$ ). This depicts the extent to which some facets are embraced while others are not. For instance, while the majority of students believe emerging technologies will have a positive impact on their profession, most have not had any programming experience or have not taken the pain to learn about it.

TABLE II. DESCRIPTIVE STATISTICS ON ACCEPTANCE AND

\begin{tabular}{|c|c|c|c|}
\hline Notations & Items & Mean & SD \\
\hline ETB30 & $\begin{array}{l}\text { Emerging Technologies for Business } \\
\text { More extensive data analysis and use of } \\
\text { emerging technology results in more insights }\end{array}$ & $\begin{array}{l}8.6425 \\
8.5800\end{array}$ & 2.2130 \\
\hline ETB31 & $\begin{array}{l}\text { Faster data analysis and use of emerging } \\
\text { technologies results in increased speed to } \\
\text { insight }\end{array}$ & 8.6000 & 2.0300 \\
\hline ETB32 & $\begin{array}{l}\text { Emerging technologies enhance } R \& D \\
\text { capabilities in next-gen products }\end{array}$ & 8.5930 & 1.9630 \\
\hline ETB33 & $\begin{array}{l}\text { Emerging technology improves the efficiency } \\
\text { of internal processes (operations) }\end{array}$ & 8.7200 & 1.9740 \\
\hline ETB34 & $\begin{array}{l}\text { Emerging technology results in better } \\
\text { understanding of customers or prospects }\end{array}$ & 8.3070 & 2.2330 \\
\hline ETB35 & $\begin{array}{l}\text { Emerging technology drives competitive } \\
\text { advantage }\end{array}$ & 8.7530 & 1.9960 \\
\hline ETB36 & Emerging technology drives cost reduction & 8.8800 & 6.9090 \\
\hline ETB37 & $\begin{array}{l}\text { Emerging technologies improve the efficiency } \\
\text { of external processes (value chain) }\end{array}$ & 8.7070 & 1.7870 \\
\hline & Embracing Emerging Technologies & 7.2898 & \\
\hline EET38 & $\begin{array}{l}\text { I have taken (will take) a course with issues of } \\
\text { emerging technologies }\end{array}$ & 6.8260 & 2.9400 \\
\hline EET39 & $\begin{array}{l}\text { Emerging technologies will not render many in } \\
\text { my area of specialisation jobless }\end{array}$ & 5.9730 & 3.1560 \\
\hline EET40 & $\begin{array}{l}\text { Emerging technologies will have a positive } \\
\text { effect on my profession }\end{array}$ & 8.3360 & 2.0870 \\
\hline
\end{tabular}

\begin{tabular}{|c|c|c|c|}
\hline \multirow[t]{2}{*}{ EET41 } & tended & 6.8050 & 3.0320 \\
\hline & $\begin{array}{l}\text { program/seminar/conference where emerging } \\
\text { technologies were discussed }\end{array}$ & & \\
\hline EET42 & $\begin{array}{l}\text { I have an interest in learning about emerging } \\
\text { technologies }\end{array}$ & 8.0870 & 2.2550 \\
\hline EET43 & $\begin{array}{l}\text { I am learning or I have learnt computer coding } \\
\text { or programming }\end{array}$ & 4.4230 & 3.2940 \\
\hline EET44 & $\begin{array}{l}\text { My course will prepare me to work in an } \\
\text { environment where emerging technologies are } \\
\text { used predominantly }\end{array}$ & 7.1280 & 2.7300 \\
\hline EET45 & I am excited about new technologies & 8.2080 & 2.1590 \\
\hline EET46 & $\begin{array}{l}\text { My programme should be updated to include } \\
\text { more learning objectives relating to emerging } \\
\text { technologies }\end{array}$ & 8.3490 & 2.1420 \\
\hline EET47 & $\begin{array}{l}\text { Examinations should test issues relating to } \\
\text { emerging technology application in my } \\
\text { discipline }\end{array}$ & 7.4900 & 2.4970 \\
\hline EET48 & $\begin{array}{l}\text { Emerging technologies will make the world } \\
\text { better }\end{array}$ & 8.2350 & 2.1780 \\
\hline EET49 & $\begin{array}{l}\text { Emerging technologies pose risks that can be } \\
\text { managed }\end{array}$ & 7.6170 & 2.2720 \\
\hline
\end{tabular}

As regards the knowledge of emerging technologies, the study recorded a grand mean of $6.57(\min =5.25, \max =7.44)$ portraying the low knowledge of students on some of the popular emerging technologies. The top four are IoT, Mobility technology, digital service delivery and cybersecurity. The bottom four are blockchain, quantum computing, big data analytics, and robotics.

\begin{tabular}{clcc} 
TABLE III. & \multicolumn{3}{c}{$\begin{array}{c}\text { DESCRIPTIVE STATISTICS ON KNOWLEDGE OF } \\
\text { EMERGING TECHNOLOGIES }\end{array}$} \\
\hline Notations & Items & Mean & SD \\
\hline & Knowledge of Emerging Technologies & 6.5718 & \\
KEM50 & Artificial Intelligence & 6.9130 & 2.9620 \\
KEM51 & 3D Printing & 6.4800 & 2.9930 \\
KEM52 & Robotics & 6.4070 & 2.9760 \\
KEM53 & Distributed ledger technology (blockchain) & 5.2530 & 3.2190 \\
KEM54 & Big Data and analytics & 6.1070 & 3.2040 \\
KEM55 & Internet of things (IoT) & 7.4400 & 2.6320 \\
KEM56 & Mobility technology & 7.1270 & 2.7040 \\
KEM57 & Social collaboration & 6.9000 & 2.8650 \\
KEM58 & Digital service delivery & 7.0600 & 2.7910 \\
KEM59 & Cybersecurity & 7.0330 & 2.9470 \\
KEM60 & Augmented and virtual reality & 6.4470 & 2.9520 \\
KEM61 & Cloud computing & 6.8270 & 3.1040 \\
KEM62 & Quantum computing & 5.4400 & 3.4460 \\
\hline
\end{tabular}

\section{Structural Model Analysis}

The results of the internal consistency tests presented in Table IV are in line with the rule of thumb of 0.7 and above based on both the Cronbach's alpha [27, 28] and the composite reliability [29, 30]. Also, the convergence reliability indicated by the average variance extracted (AVE) is above the threshold of 0.5 [23]. The discriminant validity test presented in Table $\mathrm{V}$ shows that the square root of each factor's AVE must be larger than the cross-correlations between the factors. In addition, the VIF test to examine the tolerance level also falls below the rule of thumb of 10 [31]. We thus proceed to test for statistical significance of the relationships between the various constructs.

TABLE IV. COMPOSITE AND CONVERGENCE RELIABILITY

\begin{tabular}{llll}
\multicolumn{4}{c}{ TESTS } \\
Constructs & CA & CR & AVE \\
\hline CSR & 0.9503 & 0.9576 & 0.7152 \\
Sustainability & 0.9804 & 0.9824 & 0.8236 \\
Embracing emerging technologies & 0.8863 & 0.9093 & 0.5384 \\
Emerging technologies for business & 0.9365 & 0.9532 & 0.7316 \\
Knowledge of emerging technologies & 0.8086 & 0.8728 & 0.6320 \\
\hline
\end{tabular}


TABLE V. DISCRIMINANT VALIDITY AND VARIANCE INFLATION FACTOR TESTS

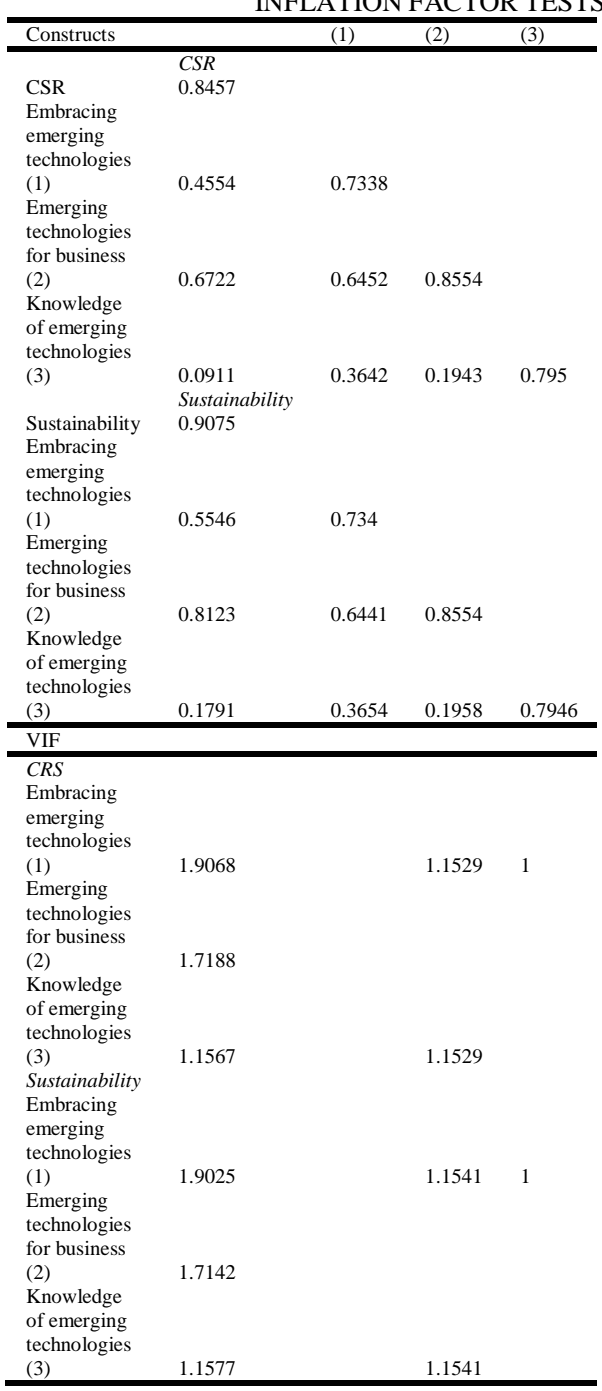

\section{CSR, Sustainability and Emerging Technologies}

The results of the structural equation model 1 are presented in Table VI and Fig. 1 below. The results indicated that embracing emerging technologies among students increases their concern for CSR but at an insignificant level. The students that embrace emerging technologies are able to make business cases from these technologies. This is confirmed by the positive path coefficient which is significant at $1 \%$ level of significance. Also, students embracing emerging technologies also enhance their knowledge in the emerging technologies as revealed by the positive and significant path coefficient. Among the three exogenous variables hypothesized to impact CSR, only the ability of students to make a business case from these technologies has a positive significant effect at $1 \%$. Knowledge of emerging technologies enters the structural model with a negative effect suggesting that the mere knowledge of these technologies alone does not enhance the concern for CSR. This result, however, is not significant. In like manner, knowledge of emerging technologies does not enhance the business case students make from these technologies. This result is also insignificant. The effect of these results reveals the path through which the issues of emerging technologies increase the concern of CSR among students. First, when they embrace the emerging technologies, it will enable them to also go ahead to explore it and thus have higher knowledge in it. Yet, this may not necessarily affect their concern for CSR. To enhance their concern of CSR, the students first embrace the technologies, then they make business cases from these technologies and this eventually enhances their concern for these new technologies.

TABLE VI. STRUCTURAL MODEL STATISTICS FOR CSR

\begin{tabular}{|c|c|c|c|}
\hline Hypothesis Path & Coefficient & $\begin{array}{l}p- \\
\text { values }\end{array}$ & Result \\
\hline Embracing emerging technologies $\rightarrow$ CSR & 0.0601 & 0.5834 & Rejected \\
\hline Knowledge of emerging technologies $\rightarrow$ CSR & -0.0560 & 0.4953 & Rejected \\
\hline Emerging technologies for business $\rightarrow$ CSR & 0.6443 & 0.0000 & Accepted \\
\hline $\begin{array}{l}\text { Knowledge of emerging technologies } \rightarrow \text { Emerging } \\
\text { technologies for business }\end{array}$ & -0.0469 & 0.5224 & Rejected \\
\hline $\begin{array}{l}\text { Embracing emerging technologies } \rightarrow \text { Emerging } \\
\text { technologies for business }\end{array}$ & 0.6623 & 0.0000 & Accepted \\
\hline $\begin{array}{l}\text { Embracing emerging technologies } \rightarrow \text { Knowledge } \\
\text { of emerging technologies }\end{array}$ & 0.3642 & 0.0001 & Accepted \\
\hline $\mathrm{R}^{2}$ & 0.455 & & \\
\hline Adj. $\mathrm{R}^{2}$ & 0.444 & & \\
\hline$Q^{2}$ & 0.283 & & \\
\hline
\end{tabular}

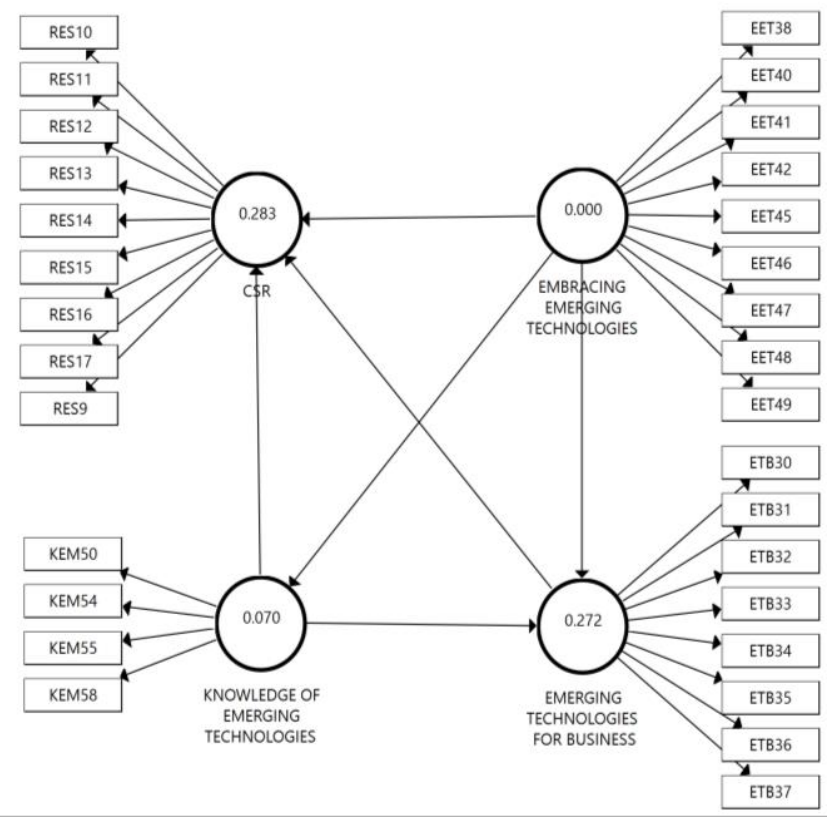

Fig. 1. PATH MODEL FOR CSR

A similar result has been evidenced in the case of Table VII and Fig. 2. There is a high relationship between CSR and sustainability. A preliminary discriminant analysis of a bigger model with both CSR and sustainability with a nexus from CSR to sustainability revealed that the discriminant validity rule is defied. This result is not presented here but available on request. The effect is that there is a need to develop separate models for the endogenous variables. Generally, the results are similar to what was found in the case of CSR. Specifically, the result also reveals that embracing emerging technologies can positively enhance the knowledge of students about those technologies but there may not be a significant effect from the knowledge on the concern for sustainability. One difference, in this case, is that knowledge of emerging technologies positively affects the concern for sustainability but at an insignificant level. Also, as evidenced in Model 1, embracing emerging technologies enhances the ability of business students to make a business 
case from the technologies and that eventually enhances the student's concern for sustainability.

\begin{tabular}{|c|c|c|c|}
\hline Hypothesis Path & $\begin{array}{c}\text { Coefficien } \\
t\end{array}$ & $\begin{array}{c}p- \\
\text { values }\end{array}$ & Result \\
\hline Embracing emerging technologies $\rightarrow$ Sustainability & 0.0503 & 0.5151 & Rejected \\
\hline Knowledge of emerging technologies $\rightarrow$ Sustainability & 0.0083 & 0.8807 & Rejected \\
\hline Emerging technologies for business $\rightarrow$ & 0.7783 & 0.0000 & Accepted \\
\hline Sustainability & & & \\
\hline $\begin{array}{l}\text { Knowledge of emerging technologies } \rightarrow \text { Emerging } \\
\text { technologies for business }\end{array}$ & -0.0457 & 0.5330 & Rejected \\
\hline $\begin{array}{l}\text { Embracing emerging technologies } \rightarrow \text { Emerging } \\
\text { technologies for business }\end{array}$ & 0.6608 & 0.0000 & Accepted \\
\hline $\begin{array}{l}\text { Embracing emerging technologies } \rightarrow \text { Knowledge of } \\
\text { emerging technologies }\end{array}$ & 0.3654 & 0.0000 & Accepted \\
\hline $\mathrm{R}^{2}$ & 0.662 & & \\
\hline Adj. $R^{2}$ & 0.655 & & \\
\hline $\mathrm{Q}^{2}$ & 0.496 & & \\
\hline
\end{tabular}

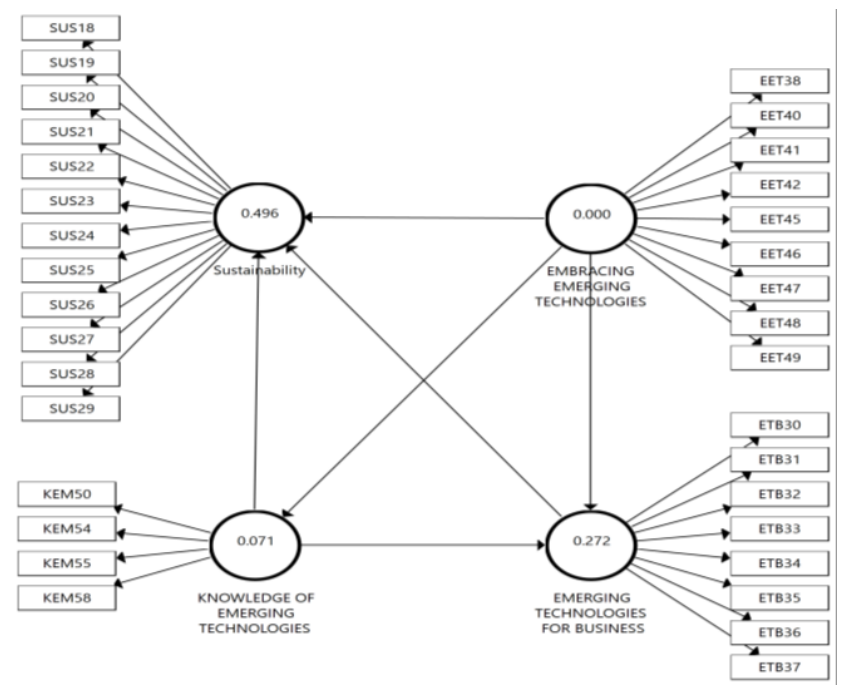

Fig. 2. PATH MODEL FOR SUSTAINABILITY

\section{CONCLUSIONS}

Concern for CSR and sustainability continue to grow with heightened concerns as a result of the fourth industrial revolution. Consequently, large corporations and organizations have acted in various ways to show their commitment to actions which are aimed at enhancing the ethical quotient of their employees and thus build an organizational culture with high concern for CSR and sustainability. Research in this area has been predominantly done outside the African context and the Ghanaian context especially in examining the nexus between the two concepts and emerging technologies. Ethical training has been advocated to be a key content of the curriculum of business schools, but there continue to be improvements that need to be made as the business models of organizations evolve. The current study employed a total sample of 150 business students of the premier university in Ghana, the University of Ghana Business School, to examine how students' embracing, knowledge and ability to make business cases out of emerging technologies affect their concern for either CSR or sustainability.

The results indicated that embracing emerging technology by business students enhance their knowledge showing that those who have an interest in knowing about these technologies eventually take steps to enhance their knowledge in them. Nevertheless, the mere knowledge of the technologies does not reflect in either the concern for CSR or sustainability among students. The path that leads to either the enhancement of the concern for CSR or sustainability flows in this wise. First, students embrace the emerging technologies, they then decipher the business cases and implications of the technologies and finally end up having higher concern for CSR and sustainability.

The current study has implications for policy, practice and future research. The results have implications for educational policies around ethics, CSR and sustainability. The national accreditation board should lead the frontier for business schools to beef up their curriculum with ethics, CSR and sustainability issues. Also, business schools should take the step to inculcate lessons around emerging technologies. For example, emerging technologies at their early adoption stage or inception stages should be discussed since they may eventually end up accepted and that may disadvantage students in case they are not aware of it. There is the need to inculcate into students the ability to make business cases out of what they learn, critically examining what implications they may have on CSR and sustainability. Thus, case studybased teaching on emerging technologies is recommended a teaching pedagogy that inculcates a more practical look at emerging technologies (and not only the legacy technologies). Also, issues of sustainability should be paramount, covering sustainability at the micro, macro, and meta-levels of the economy. In effect, concerns of the sustainable development goals should be topical in the teaching and research of faculty. The current study is an exploratory examination and is limited in various ways. Essentially, future studies could provide a more theoreticalbased examination using the technology acceptance model (TAM) and other relevant theories.

\section{ACKNOWLEDGMENT}

We appreciate the support of Divine Mensah Duho during the data collection and data entry.

\section{REFERENCES}

[1] S. Waschull, J. Bokhorst, E. Molleman, and J. Wortmann, "Work design in future industrial production: Transforming towards cyberphysical systems," Computers \& Industrial Engineering, 2019.

[2] P. Leitao, S. Karnouskos, L. Ribeiro, J. Lee, T. Strasser, and A. W. Colombo, "Smart agents in industrial cyber-physical systems," Proceedings of the IEEE, vol. 104, pp. 1086-1101, 2016.

[3] J. H. Moor, "Why we need better ethics for emerging technologies," Ethics and Information Technology, vol. 7, pp. 111-119, 2005.

[4] P. A. Brey, "Anticipatory ethics for emerging technologies," NanoEthics, vol. 6, pp. 1-13, 2012.

[5] M. Larrán, J. Andrades, and J. Herrera, "An examination of attitudes and perceptions of Spanish business and accounting students toward corporate social responsibility and sustainability themes," Revista de Contabilidad, 2018.

[6] M. d. M. Alonso-Almeida, F. C. Fernández de Navarrete, and J. Rodriguez-Pomeda, "Corporate social responsibility perception in business students as future managers: a multifactorial analysis," Business Ethics: A European Review, vol. 24, pp. 1-17, 2015.

[7] R. Z. Elias, "An examination of business students' perception of corporate social responsibilities before and after bankruptcies," Journal of Business Ethics, vol. 52, pp. 267-281, 2004.

[8] G. Eweje and M. Brunton, "Ethical perceptions of business students in a New Zealand university: do gender, age and work experience matter?," Business Ethics: A European Review, vol. 19, pp. 95-111, 2010. 
[9] I. Montiel, "Corporate social responsibility and corporate sustainability: Separate pasts, common futures," Organization \& Environment, vol. 21, pp. 245-269, 2008.

[10] A. B. Carroll, "A Three-Dimensional Conceptual Model of Corporate Performance," The Academy of Management Review, vol. 4, pp. 497505, 1979

[11] WCED, Our Common Future: World Commission on Environment and Development New York: Oxford University Press, 1987.

[12] L. Frewer, "Risk perception, social trust, and public participation in strategic decision making: Implications for emerging technologies," Ambio, pp. 569-574, 1999.

[13] B. P. Green, "Emerging technologies, catastrophic risks, and ethics three strategies for reducing risk," in 2016 IEEE International Symposium on Ethics in Engineering, Science and Technology (ETHICS), 2016, pp. 1-7.

[14] A.-M. Lämsä, M. Vehkaperä, T. Puttonen, and H.-L. Pesonen, "Effect of business education on women and men students' attitudes on corporate responsibility in society," Journal of Business Ethics, vol. 82, pp. 45-58, 2008.

[15] R. Emanuel and J. Adams, "College students' perceptions of campus sustainability," International Journal of Sustainability in Higher Education, vol. 12, pp. 79-92, 2011.

[16] F. Kagawa, "Dissonance in students' perceptions of sustainable development and sustainability: Implications for curriculum change," International Journal of Sustainability in Higher Education, vol. 8, pp. 317-338, 2007

[17] M. Nejati and M. Nejati, "Assessment of sustainable university factors from the perspective of university students," Journal of Cleaner Production, vol. 48, pp. 101-107, 2013.

[18] M. Saunila, M. Nasiri, J. Ukko, and T. Rantala, "Smart technologies and corporate sustainability: The mediation effect of corporate sustainability strategy," Computers in Industry, vol. 108, pp. 178-185, 2019.

[19] V. E. Johnson and L. L. Brennan, "Examining the impact of technology on social responsibility practices," in Re-Imaging Business Ethics: Meaningful Solutions for a Global Economy, ed: Emerald Group Publishing Limited, 2002, pp. 107-123.

[20] A. Parasuraman, "Technology Readiness Index (TRI) a multiple-item scale to measure readiness to embrace new technologies," Journal of Service Research, vol. 2, pp. 307-320, 2000.

[21] D. Barclay, C. A. Higgins, and R. Thompson, "The partial least squares approach to causal modeling: personal computer adoption and use as an illustration," Technology Studies: Special Issue on Research Methodology, vol. 2, pp. 284-324, 1995.

[22] C. Ringle, S. Wende, and J. Becker, "Smartpls 3.1. 5," University of Hamburg, Hamburg, Germany, 2014.

[23] J. F. Hair Jr, G. T. M. Hult, C. Ringle, and M. Sarstedt, A primer on partial least squares structural equation modeling (PLS-SEM): Sage publications, 2016.

[24] J. F. Hair Jr, M. Sarstedt, L. Hopkins, and V. G. Kuppelwieser, "Partial least squares structural equation modeling (PLS-SEM) An emerging tool in business research," European Business Review, vol. 26, pp. 106-121, 2014.

[25] W. W. Chin, "The partial least squares approach to structural equation modeling," Modern Methods for Business Research, vol. 295, pp. 295 336, 1998.

[26] SPSS, "IBM SPSS statistics 22," New York: IBM Corp, 2013.

[27] L. J. Cronbach, "Coefficient Alpha and the internal structure of tests," Psychometrika, vol. 16, pp. 297-334, 1951.

[28] A. Leontitsis and J. Pagge, "A simulation approach on Cronbach's alpha statistical significance," Mathematics and Computers in Simulation (MATCOM), vol. 73, pp. 336-340, 2007.
[29] C. Fornell and D. F. Larcker, "Evaluating structural equation models with unobservable variables and measurement error," Journal of Marketing Research, vol. 18, pp. 39-50, 1981.

[30] J. Nunnally, "Psychometric theory. Mc Graw-Hill Publ Co," New York, 1978.

[31] R. M. O’brien, "A caution regarding rules of thumb for variance inflation factors," Quality \& Quantity, vol. 41, pp. 673-690, 2007. 